\title{
STUDIES IN SERUM ELECTROLYTES. XII. THE EFFECT OF WATER RESTRICTION IN A PATIENT WITH ADDISON'S DISEASE RECEIVING SODIUM CHLORIDE ${ }^{1}$
}

\author{
By DONALD M. WILLSON AND F. WILLIAM SUNDERMAN \\ (From the William Pepper Laboratory of Clinical Medicine, University of Pennsylvania, \\ Philadelphia)
}

(Received for publication August 18, 1938)

The efficacy of sodium salts in the treatment of adrenal cortical insufficiency in man and experimental animals has been recognized, and the changes in the distribution and excretion of water and electrolytes following their therapeutic use have been investigated $(1,2,3,4)$. This present study is concerned with the effect of variations in the total water consumption of a patient with Addison's disease receiving a relatively constant high intake of sodium chloride.

Observations in the literature concerning adrenal insufficiency suggest that the changes in the distribution of body water are secondary to changes in the distribution of sodium and potassium. The forced ingestion of water by mouth is apparently ineffective per se in preventing the development of hemoconcentration observed in insufficiency. If sufficient water be given an adrenalectomized dog receiving no cortical extract and on low intake of salt, a fairly constant fluid balance may be obtained and yet hemoconcentration may develop (5).

Hemoconcentration and dehydration are commonly observed in severe crisis. The hemoconcentration is recognized by the increased concentration of hemoglobin, the increased percentage of erythrocytes, and the small proportion of serum yielded from blood. Studies in experimental insufficiency indicate that the blood volume is diminished (6) and that the amount of interstitial fluid may be reduced as well (7). The diuresis that frequently occurs with the onset of a crisis is apparently inadequate to account for the diminution in serum volume (8). Harrop suggests that the most important factor responsible for the observed hemoconcentration is a " movement of extracellular fluid into the tissue cells" (7).

1 Aided by a grant from the Faculty Research Committee, University of Pennsylvania, Philadelphia, Pennsylvania.
Upon withdrawal of cortin from adrenalectomized dogs maintained on a sodium and chloride free diet, Swingle, Parkins, Taylor, and Hays (9) observed that hemoconcentration and circulatory collapse occurred without the loss of sodium, chloride, or water by way of the urine. Furthermore, the injection of massive doses of cortin alone brought about a dilution of the blood and a relief of symptoms. Although not entirely apparent from their data they concluded that the injection of cortical extract mobilized the accumulation of intracellular fluid and electrolytes, and shifted them from the intracellular to the extracellular and vascular compartments.

In an effort to obtain further information upon the problems of hemoconcentration and the internal shift of water in adrenal insufficiency, this study of water and electrolyte metabolism in Addison's disease was undertaken.

\section{PROCEDURE}

A patient with typical Addison's disease who had remained reasonably well-controlled on a normal diet with added salt for several months (see protocol) was selected for these observations. The experimental procedure consisted of a continuation of this dietary regimen, but with variations in the intake of water to produce periods of oliguria and polyuria.

One of us (D.M.W.) was used as a control subject for these observations under identical conditions of diet and intake of salt and water as were imposed upon the patient, but without the same limitations of activity.

A special metabolic ward and nursing staff were utilized to facilitate this investigation. Two standard diets were hashed and analyzed for their content of chloride and water. Duplicates of these two rations were served on alternate days throughout the study.

The total intake of water was calculated as the sum of the intrinsic water of the diet, beverage water, and water of oxidation of the food constituents. Intrinsic water was determined by the difference between the wet and dry weights of the two complete sample diets. The water of oxidation was computed as 1.07 grams per gram fat, 0.555 gram per gram carbohydrate, and 0.413 
gram per gram protein (10). In periods of anorexia, corrections were made for returned food.

The high intake of sodium and chloride was maintained, first by the oral administration of $\mathrm{NaCl}$ in gelatin capsules, second by seasoning of the foods (determined by differences in weight of the shaker), and third by the intrinsic salt contained in the food. Our analysis for chloride in the sample diets was 10 per cent higher than the calculated content from Sherman's Food Tables (11). Since intrinsic salt is only 14 per cent of total salt, the error introduced by the use of Sherman's figures, correcting for uneaten food, is less than 1.4 per cent. ${ }^{2}$

Measurements of the serum volume and analysis of the serum for sodium and chloride were made at appropriate intervals. Twenty-four-hour collections of urine were measured and aliquots preserved in the refrigerator under toluol. Measurements of the concentration of sodium and of chloride in the urine were made each day.

Since analyses of feces for sodium and chloride were not undertaken, the actual amounts excreted in this manner are unknown. It has been our experience that under normal circumstances and in the absence of diarrhea, the amount of chloride excreted in the feces is fairly constant. Diarrhea occurred on two days of these observations and attention is drawn to this in the text.

The methods of analysis for the mineral components are given in a previous publication of this series (15). Measurement of the serum volume was determined by the method of Sunderman and Austin (13).

\section{Preliminary control period}

Observations were begun with a stabilization period of six days during which time fluids were administered in any quantity desired. Determination of the chloride and sodium content of the urine during this period revealed a close parallelism between the intake of sodium chloride ${ }^{8}$ and the urinary excretion of both chloride and sodium (Table I). This parallelism was maintained on the second day of the experiment when the lowered ingestion of salt was reflected by its diminished excretion in the urine. It will be seen in Figure $1 A$ that there is a fairly constant difference between ingested chloride and the sodium and chloride recovered in the urine. This difference is attributed to the excretion of those ions by feces and sweat and apparently is greater

2 The recent study by Wilder et al. (12) indicates that the average daily potassium content of 4.2 grams in our diet is higher than the optimum in the treatment of Addison's disease.

8 The difference in the average content of sodium and chloride of the two diets employed was $0.8 \mathrm{~m}$.eq. and is insignificant.
TABLE I

Data on patient with adrenal insufficiency

\begin{tabular}{c|c|c|c|c|c|c|c}
\hline \hline $\begin{array}{c}\text { Day } \\
\text { of } \\
\text { experi- } \\
\text { ment }\end{array}$ & \multicolumn{2}{|c|}{ Intake } & \multicolumn{5}{|c}{ Renal excretion } \\
\cline { 2 - 6 } & $\begin{array}{c}\text { Chlo- } \\
\text { ride }\end{array}$ & $\begin{array}{l}\text { Total } \\
\text { water }\end{array}$ & Urine & Sodium & Sodium & $\begin{array}{c}\text { Chlo- } \\
\text { ride }\end{array}$ & $\begin{array}{c}\text { Chlo- } \\
\text { ride }\end{array}$ \\
\hline $\begin{array}{c}\text { m.eq. } \\
\text { per \&4 } \\
\text { hours }\end{array}$ & ml. & ml. & $\begin{array}{c}\text { m.eq. } \\
\text { per \&4 } \\
\text { hours }\end{array}$ & $\begin{array}{c}\text { m.eq. } \\
\text { per } \\
\text { liter }\end{array}$ & $\begin{array}{c}\text { m. eq. } \\
\text { per \&4 } \\
\text { hours }\end{array}$ & $\begin{array}{c}\text { m.eq. } \\
\text { per } \\
\text { liter }\end{array}$ \\
\hline
\end{tabular}

PRELIMINARY CONTROL PERIOD

\begin{tabular}{l|l|r|r|r|r|r|r}
\hline 1 & 238 & 3302 & 2080 & 214 & 103 & 221 & 106 \\
2 & 187 & 3293 & 1495 & 139 & 93 & 154 & 103 \\
3 & 229 & 3622 & 2160 & 209 & 97 & 224 & 104 \\
4 & 243 & 3967 & 2025 & 221 & 109 & 232 & 115 \\
5 & 238 & 3482 & 2240 & 208 & 93 & 219 & 98 \\
6 & 243 & 3214 & 2000 & 178 & 89 & 192 & 95 \\
\hline
\end{tabular}

DEHYDRATION

\begin{tabular}{r|r|r|r|r|r|r|r}
\hline 7 & 183 & 1525 & 1275 & 168 & 131 & 186 & 145 \\
8 & 221 & 1359 & 670 & 96 & 143 & 110 & 165 \\
9 & 229 & 1930 & 375 & 63 & 168 & 70 & 187 \\
10 & 229 & 2171 & 1115 & 193 & 173 & 216 & 193 \\
11 & 227 & 2013 & 520 & 96 & 185 & 107 & 205 \\
12 & 238 & 1867 & 820 & 153 & 187 & 169 & 207 \\
13 & 142 & 1489 & 670 & 125 & 183 & 144 & 215 \\
\hline
\end{tabular}

WATER AS DESIRED

\begin{tabular}{l|r|r|r|r|r|r|r}
\hline 14 & 222 & 3544 & 935 & 177 & 189 & 203 & 217 \\
15 & 234 & 2510 & 1100 & 148 & 135 & 159 & 145 \\
16 & 241 & 3847 & 1300 & 157 & 121 & 153 & 118 \\
17 & 219 & 2636 & 2300 & 204 & 89 & 215 & 93 \\
18 & 241 & 3943 & 1490 & 164 & 110 & 176 & 118 \\
\hline
\end{tabular}

WATER FORCED

\begin{tabular}{l|l|l|l|l|l|l|r}
\hline 19 & 207 & 4738 & 2975 & 191 & 64 & 212 & 71 \\
20 & 238 & 4886 & $2500^{*}$ & 162 & 65 & 196 & 78 \\
21 & 234 & 4681 & 2725 & 202 & 74 & 224 & 82 \\
22 & 190 & 4414 & $1780 \dagger$ & 151 & 85 & 179 & 100 \\
23 & 209 & 4131 & 2030 & 171 & 84 & 199 & 98 \\
24 & 212 & 4416 & 2390 & 177 & 74 & 209 & 87 \\
25 & 224 & 4184 & 2310 & 174 & 75 & 194 & 84 \\
26 & 236 & 4858 & 2315 & 182 & 79 & 197 & 85 \\
\hline
\end{tabular}

FINAL CONTROL PERIOD

\begin{tabular}{l|l|r|r|r|r|r|r}
\hline 27 & 224 & 3666 & 2040 & 158 & 77 & 177 & 86 \\
28 & 243 & 3849 & 1780 & 173 & 97 & 186 & 104 \\
29 & 221 & 3888 & 2525 & 190 & 75 & 198 & 78 \\
30 & 241 & 3977 & 2455 & 178 & 73 & 191 & 78 \\
31 & 219 & 3673 & 2060 & 152 & 74 & 167 & 81 \\
32 & 241 & 3847 & 1710 & 146 & 85 & 159 & 93 \\
\hline
\end{tabular}

* 210 cc. watery stool.

$\dagger 250$ cc. watery stool.

for sodium than for chloride. The divergency of the curves of chloride intake and the output on the last day of this stabilization period is attrib- 
A

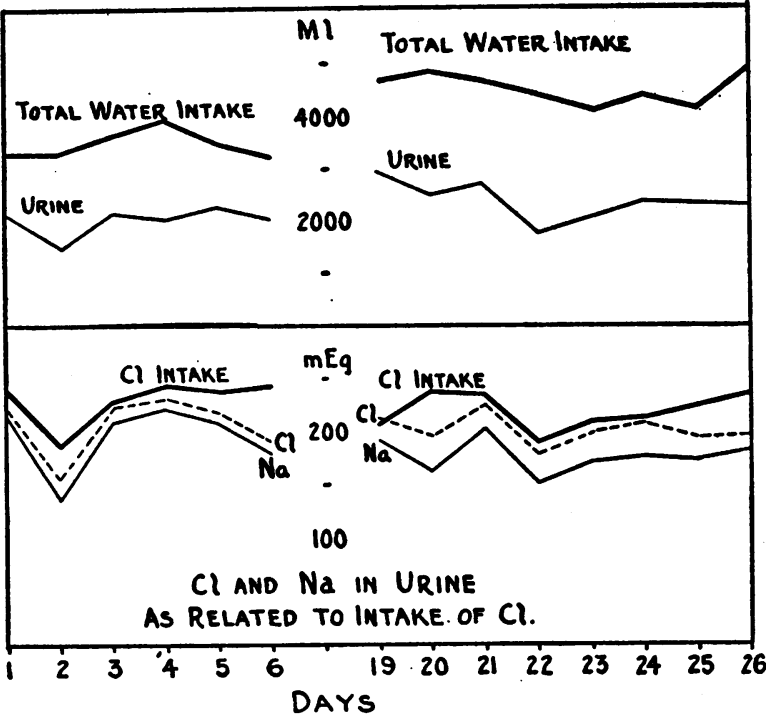

Fig. 1. Patient with Adrenal Insufficiency

$A$. Preliminary control period; fluids as desired. $B$. Period of high fluid intake.

utable to vomiting which occurred three hours after the evening meal.

\section{Dehydration in patient with Addison's disease}

Following stabilization, the fluid intake of the patient was reduced sharply, while the intake of sodium chloride was maintained at the previous high level. This was associated with greatly reduced volumes of urine, as little as $375 \mathrm{cc}$. being excreted in one twenty-four-hour period (Figure $2 A$ ). Associated with the oliguria there was a gradually increasing concentration of sodium and chloride in the urine (Table I). However, this increase was only of a moderate degree, which during the final three days of dehydration tended toward a constant level, and suggests a diminution in the patient's ability to concentrate sodium and chloride in small volumes of urine. This contrasts with the lack of such failure in the control subject under similar circumstances (Table II). Compared with the previous control period the amounts of sodium and chloride excreted by the patient were diminished. Since bowel activity appeared to be unaffected by the dehydration, we may assume that no appreciable variations in the amount of salt excreted by that channel occurred and that this apparent retention is a real one.

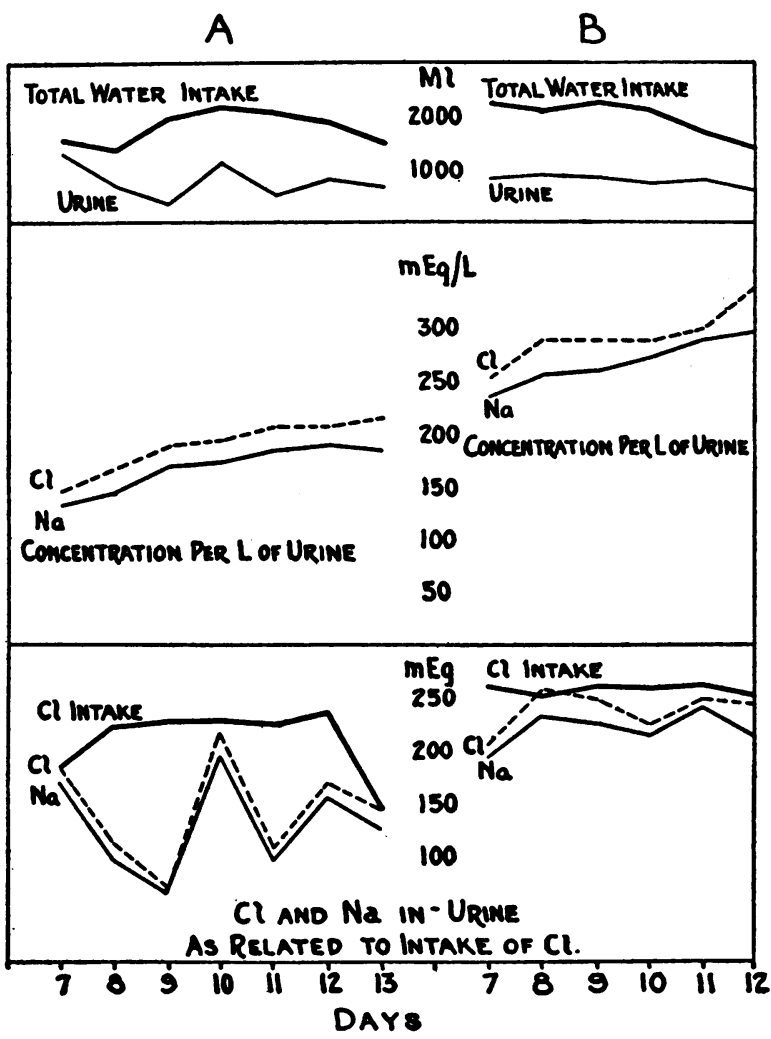

Fig. 2

$A$. Dehydration in patient with adrenal insufficiency. $B$. Dehydration in control subject.

TABLE II

Data on control subject

\begin{tabular}{|c|c|c|c|c|c|c|c|}
\hline \multirow{2}{*}{$\begin{array}{c}\text { Day } \\
\text { of } \\
\text { experi- } \\
\text { ment }\end{array}$} & \multicolumn{2}{|c|}{ Intake } & \multicolumn{5}{|c|}{ Renal excretion } \\
\hline & $\underset{\text { ride }}{\text { Chlo- }}$ & $\begin{array}{l}\text { Total } \\
\text { water }\end{array}$ & Urine & Sodium & Sodium & $\begin{array}{l}\text { Chlo- } \\
\text { ride }\end{array}$ & $\begin{array}{l}\text { Chlo- } \\
\text { ride }\end{array}$ \\
\hline & $\begin{array}{l}\text { m. eq. } \\
\text { per } 84 \\
\text { hours }\end{array}$ & $m l$. & $m l$. & $\begin{array}{l}\text { m. eq. } \\
\text { per } 84 \\
\text { hours }\end{array}$ & $\begin{array}{c}\text { m.eq. } \\
\text { per } \\
\text { liter }\end{array}$ & $\begin{array}{l}\text { m. eq. } \\
\text { per } 24 \\
\text { hours }\end{array}$ & $\begin{array}{c}\text { m. eq. } \\
\text { per } \\
\text { liter }\end{array}$ \\
\hline \multicolumn{8}{|c|}{ DEHYDRATION } \\
\hline $\begin{array}{r}7 \\
8 \\
9 \\
10 \\
11 \\
12\end{array}$ & $\begin{array}{l}262 \\
251 \\
262 \\
260 \\
262 \\
253\end{array}$ & $\begin{array}{l}2221 \\
2112 \\
2241 \\
2142 \\
1691 \\
1402\end{array}$ & $\begin{array}{l}820 \\
900 \\
870 \\
790 \\
835 \\
730\end{array}$ & $\begin{array}{l}193 \\
231 \\
225 \\
215 \\
241 \\
216\end{array}$ & $\begin{array}{l}235 \\
256 \\
259 \\
272 \\
289 \\
296\end{array}$ & $\begin{array}{l}206 \\
259 \\
250 \\
227 \\
250 \\
247\end{array}$ & $\begin{array}{l}252 \\
288 \\
287 \\
288 \\
300 \\
338\end{array}$ \\
\hline
\end{tabular}

WATER FORCED

\begin{tabular}{r|r|r|r|r|r|r|r}
\hline 13 & 262 & 4791 & 1440 & 279 & 194 & 264 & 183 \\
14 & 262 & 4752 & 3040 & 243 & 80 & 244 & 74 \\
15 & 265 & 5091 & 2820 & 231 & 82 & 231 & 82 \\
16 & 263 & 4352 & 2580 & 233 & 90 & 213 & 82 \\
\hline
\end{tabular}


On the tenth experimental day a relatively large volume of urine was excreted. The concentrations of sodium and chloride remained elevated in spite of this increased volume and the total amounts of sodium and chloride excreted attained the range observed during the days of the previous control period. Hence, during the dehydration period sodium and chloride were apparently retained by the body awaiting only adequate diuresis for its excretion.

The loss of four and a half pounds of body weight during this seven-day period attests the rigidity of fluid restriction. As would be expected in one whose liquids had been so stringently reduced, the patient soon became exceedingly thirsty. Mouth, lips, and throat were very dry and uncomfortable. Cheeks and eyes became sunken, pigmentation was more pronounced, and it became difficult for her to eat all of the daily ration because of dryness. Although anorexia and weakness increased, it was not until the last two days of dehydration that they became seriously aggravated. During these final days the patient was too weak to get out of bed, and lay quietly all day, moistening her lips with ice. Tissue turgor was markedly diminished, but no change in blood pressure was noted. In spite of the rigors of this regimen, the patient professed willingness to continue and was conscientious in expectorating all of the melted ice but was unable to take her full quota of salt during the final twenty-four-hour period.

\section{Dehydration in the control subject}

The effects of dehydration in the control subject are interpolated at this point for comparison with the results obtained from the observations on the patient, and the data are shown in Table II and Figure $2 B$. Under identical conditions (excepting that activity was not restricted) the volumes of urine in the control subject diminished to levels comparable with those of the patient, and in the course of six days, there was a loss of five pounds in body weight. As dehydration developed, the concentration of sodium and of chloride in the urine gradually increased until on the final day it was about 60 per cent above the maximum concentration exhibited in the urine of the patient, and the continuing rise in the con- centration curve (Figure $2 B$ ) suggests that the limits of the concentrating power might not have been reached. No retention of sodium or chloride occurred during this phase of water deprivation.

\section{Post-dehydration period in patient with Addison's disease}

Upon the removal of fluid restriction our patient consumed three liters of water within eight hours, and a rapid improvement in general condition was noted; the extreme anorexia disappeared and moderate physical activity was quickly resumed. The concentration of hemoglobin dropped 2.8 grams per $100 \mathrm{cc}$. in twenty-four hours, suggesting rapid dilution of the blood. It required several days, however, for the body weight, deepened pigmentation, and diminished tissue turgor to return to their usual state. The great increase of ingested water the first day following dehydration was not reflected by appreciable diuresis and concentrations of sodium and chloride in the urine on this day reached maximum levels (Table I). On subsequent days the volume of urine increased, and rapid fall in concentrations of sodium and chloride was noted. This occurred in spite of the previous retention of sodium and chloride. No diarrhea was present which might have carried off the retained salt.

\section{Effects of a high fluid intake on patient with Addison's disease. (Water forced)}

The next step in the investigation consisted of an attempt to cause an acceleration of the loss of sodium and chloride from the body through the urine by means of a diuresis induced by a high intake of fluid. Over an eight-day period, ingested water approximated 4,500 cc. per day. resulting in the excretion of large volumes of urine. The concentration of sodium and chloride in the urine decreased, but the average daily output of these ions was greater than for any period excepting the preliminary control period.

The total daily urinary excretion of sodium and chloride in the control subject following diuresis by the ingestion of water was essentially the same as obtained during the period of dehydration. Apparently, within the scope of this experiment, the normal kidney easily excretes relatively large 
amounts of salt whether fluids are restricted or forced.

\section{Final control period}

The patient was followed for an additional six days during which time fluids were ingested as desired. No unusual change in the excretion of sodium and chloride occurred during this period of observation.

\section{Chloride and sodium balances according to periods}

A summation of the uncorrected chloride balances (Table IIIA) shows agreement in the third and fifth periods (control) but relative to these, a retention in the first period. From this it is inferred that at the start of these observations the patient might not have been quite in balance and that a consideration of the data according to periods might better begin with the second (de- hydration) period. This has been undertaken in Tables IIIB and IIIC. In Table IIIA it will be observed that the ratio of sodium to chloride excretion in the urine is fairly constant throughout all of the periods of study.

In Table IIIB are presented our calculations of the corrected daily chloride balance for the last four periods. For the purpose of these calculations it is assumed that a complete chloride balance was achieved at the end of the fifth period and that throughout the total period of experimentation there was a constant daily loss of chloride amounting to $44.8 \mathrm{~m}$.eq. from other channels than urine." In Table IIIC are presented our evaluations of the sodium output assuming that its intake is proportional to the chloride intake and that there occurred a constant loss of

$$
\left(\frac{5765 \text { m.eq. }-4596 \text { m.eq. }}{26 \text { days }}=44.8 \text { m.eq. per day }\right) \text {. }
$$

TABLE III

(A)

Summary of data on patient with adrenal insufficiency

\begin{tabular}{|c|c|c|c|c|c|c|c|}
\hline Period & Days & $\mathrm{Cl}$ intake & $\begin{array}{l}\text { Cl output } \\
\text { in urine }\end{array}$ & $\begin{array}{c}\text { Cl intake } \\
\text { less Cl } \\
\text { output in } \\
\text { urine }\end{array}$ & $\begin{array}{l}\text { Uncorrected } \\
\text { average } \\
\text { daily } \mathrm{Cl} \\
\text { balance }\end{array}$ & $\begin{array}{l}\text { Na out- } \\
\text { put in } \\
\text { urine }\end{array}$ & $\frac{\text { Na output in urine }}{\text { Cl output in urine }}$ \\
\hline $\begin{array}{l}\text { 1. Control } \ldots \ldots \ldots \ldots \ldots \ldots \ldots \ldots \ldots \\
\text { 2. Dehydration } \ldots \ldots \ldots \ldots \ldots \ldots \ldots \ldots \ldots \\
\text { 3. Water as desired-control } \ldots \ldots \ldots \ldots \ldots \\
\text { 4. Water forced } \ldots \ldots \ldots \ldots \ldots \ldots \ldots \ldots \ldots \\
\text { 5. Control } \ldots \ldots \ldots \ldots \ldots \ldots \ldots \ldots \ldots\end{array}$ & $\begin{array}{l}6 \\
7 \\
5 \\
8 \\
6\end{array}$ & $\begin{array}{l}m . e q . \\
1378 \\
1469 \\
1157 \\
1750 \\
1389\end{array}$ & $\begin{array}{r}m . e q . \\
1242 \\
1002 \\
906 \\
1610 \\
1078\end{array}$ & $\begin{array}{r}\text { m.eq. } \\
136 \\
467 \\
251 \\
140 \\
311\end{array}$ & $\begin{array}{l}m . e q \\
+23 \\
+67 \\
+50 \\
+17 \\
+52\end{array}$ & $\begin{array}{r}\text { m.eq. } \\
1169 \\
894 \\
850 \\
1410 \\
997\end{array}$ & $\begin{array}{l}\text { ratio } \\
0.94 \\
0.89 \\
0.94 \\
0.88 \\
0.93\end{array}$ \\
\hline
\end{tabular}

(B)

Cumulative chloride balance

\begin{tabular}{|c|c|c|c|c|c|c|c|}
\hline Period & $\begin{array}{l}\text { Total } \\
\text { days }\end{array}$ & $\begin{array}{l}\text { Cumulative } \\
\text { Cl intake }\end{array}$ & $\begin{array}{l}\text { Cumulative } \\
\text { Cl output } \\
\text { in urine }\end{array}$ & $\begin{array}{l}\text { Cumulative } \\
\text { corrected } \\
\mathrm{Cl} \text { output }\end{array}$ & $\begin{array}{l}\text { Cumulative } \\
\mathrm{Cl} \text { balance }\end{array}$ & $\begin{array}{l}\mathrm{Cl} \text { bal- } \\
\text { ance for } \\
\text { period }\end{array}$ & $\begin{array}{l}\text { Corrected } \\
\text { average daily } \\
\mathrm{Cl} \text { balance }\end{array}$ \\
\hline 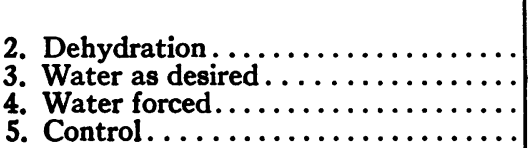 & $\begin{array}{r}7 \\
12 \\
20 \\
26\end{array}$ & $\begin{array}{l}\text { m.eq. } \\
1469 \\
2626 \\
4376 \\
5765\end{array}$ & $\begin{array}{l}\text { m. eq. } \\
1002 \\
1908 \\
3518 \\
4596\end{array}$ & $\begin{array}{l}m . e q . \\
1316 \\
2448 \\
4418 \\
5765\end{array}$ & $\begin{array}{c}\text { m.eq. } \\
+153 \\
+178 \\
-42 \\
0\end{array}$ & $\begin{array}{l}\text { m. eq. } \\
+153 \\
+\quad 25 \\
-220 \\
+\quad 42\end{array}$ & $\begin{array}{r}m . e q . \\
+21.9 \\
+\quad 5.0 \\
-27.5 \\
+\quad 7.0\end{array}$ \\
\hline
\end{tabular}

(c)

Cumulative sodium balance

\begin{tabular}{|c|c|c|c|c|c|c|c|}
\hline Period & $\begin{array}{l}\text { Total } \\
\text { days }\end{array}$ & $\begin{array}{l}\text { Cumulative } \\
\text { Na intake }\end{array}$ & $\begin{array}{l}\text { Cumulative } \\
\text { Na output } \\
\text { in urine }\end{array}$ & $\begin{array}{l}\text { Cumulative } \\
\text { corrected } \\
\text { Na output }\end{array}$ & $\begin{array}{l}\text { Cumulative } \\
\text { Na balance }\end{array}$ & $\begin{array}{c}\text { Na bal- } \\
\text { ance for } \\
\text { period }\end{array}$ & $\begin{array}{c}\text { Corrected } \\
\text { average daily } \\
\mathrm{Na} \text { balance }\end{array}$ \\
\hline $\begin{array}{l}\text { 2. Dehydration } \ldots \ldots \ldots \ldots \ldots \ldots \ldots \ldots \ldots \\
\text { 3. Water as desired } \ldots \ldots \ldots \ldots \ldots \ldots \ldots \ldots \\
\text { 4. Water forced } \ldots \ldots \ldots \ldots \ldots \ldots \ldots \ldots \ldots \ldots \\
\text { 5. Control } \ldots \ldots \ldots \ldots \ldots \ldots \ldots \ldots\end{array}$ & $\begin{array}{r}7 \\
12 \\
20 \\
26\end{array}$ & $\begin{array}{l}\text { m.eq. } \\
1469 \\
2626 \\
4376 \\
5765\end{array}$ & $\begin{array}{r}\text { m. eq. } \\
894 \\
1744 \\
3154 \\
4151\end{array}$ & $\begin{array}{l}\text { m. eq. } \\
1329 \\
2489 \\
4396 \\
5765\end{array}$ & $\begin{array}{c}\text { m.eq. } \\
+140 \\
+137 \\
-20 \\
0\end{array}$ & $\begin{array}{r}\text { m. eq. } \\
+140 \\
-\quad 3 \\
-157 \\
+\quad 20\end{array}$ & $\begin{array}{r}\text { m. eq. } \\
+20.0 \\
-\quad 0.6 \\
-19.6 \\
+\quad 3.3\end{array}$ \\
\hline
\end{tabular}


62.1 m.eq. of sodium per day from other channels than urine. ${ }^{5}$

Allowing for uncertainties in these assumptions the picture would seem to be fairly clearthere was retention of both sodium and chloride during the dehydration period and a washing out of these ions in the forced water period.

\section{Serum analyses}

The results of the analyses of the serum taken during various phases of this experimental procedure are given in Table IV. It will be seen

TABLE IV

Serum studies in patient with adrenal insufficiency

\begin{tabular}{|c|c|c|c|c|c|c|}
\hline Period & $\begin{array}{c}\text { Body } \\
\text { weight }\end{array}$ & $\begin{array}{l}\text { So- } \\
\text { dium }\end{array}$ & $\begin{array}{l}\text { Chlo- } \\
\text { ride }\end{array}$ & $\begin{array}{l}\text { So- } \\
\text { dium } \\
\text { con- } \\
\text { tent }\end{array}$ & $\begin{array}{l}\text { Chlo- } \\
\text { ride } \\
\text { con- } \\
\text { tent }\end{array}$ & $\begin{array}{l}\text { Serum } \\
\text { volume }\end{array}$ \\
\hline & kilos & $\begin{array}{c}\text { m. eq. } \\
\text { per } \\
\text { liter }\end{array}$ & $\begin{array}{c}\text { m. eq. } \\
\text { per } \\
\text { liter }\end{array}$ & m. eq. & m.eq. & $\begin{array}{c}\text { ml. per } \\
\text { kgm. } \\
\text { body } \\
\text { weight }\end{array}$ \\
\hline $\begin{array}{l}\text { control ........ } \\
\text { Dehydration ..... } \\
\text { Water forced ..... } \\
\text { Final control ..... }\end{array}$ & $\begin{array}{l}60.5 \\
58.4 \\
59.4 \\
59.1\end{array}$ & $\begin{array}{l}129.4 \\
140.3 \\
127.5 \\
126.8\end{array}$ & $\begin{array}{l}100.7 \\
107.1 \\
103.0 \\
101.6\end{array}$ & $\begin{array}{l}268.6 \\
286.8 \\
285.0\end{array}$ & $\begin{array}{l}205.6 \\
231.6 \\
228.3\end{array}$ & $\begin{array}{l}32.8 \\
37.9 \\
38.0\end{array}$ \\
\hline
\end{tabular}

that the concentration of sodium in the serum was low in the preliminary control period, forced water, and final control periods. In these same periods the chloride concentrations were within the normal range. During the period of dehydration both the sodium and chloride concentrations in the serum were increased to the upper normal range for these components or even higher for sodium.

Studies of serum volume in this patient were of particular interest. During the period of dehydration the serum volume for this patient was $32.8 \mathrm{ml}$. per $\mathrm{kgm}$. of body weight, which is the lowest value for serum volume obtained in this laboratory. Moreover, the serum at this time yielded evidence of an increased concentration of the serum proteins since the specific gravity was 1.0295 at $20^{\circ} / 20^{\circ}$. The volumes of serum per kilogram of body weight measured during the final control period and during the phase of forced fluid intake were 38.0 and $37.9 \mathrm{ml}$. respectively.

\footnotetext{
55765 m.eq. -4151 m.eq. 26 days
}

These values are still considerably below our range of values for normal individuals (45 to $55 \mathrm{ml}$.).

The control subject differed from the patient with Addison's disease in that variations of fluid intake had no effect upon the concentration of the electrolytes in the blood serum. Likewise, the serum volume in the control subject was essentially the same during dehydration and hydration.

\section{DISCUSSION}

Impairment of renal function in our patient is suggested by the retention of sodium and chloride during the period of oliguria, in contrast to the lack of such retention in the normal individual studied under the same conditions. In addition, the patient had a diminished urea clearance varying from 23 to 33 per cent of average normal function. It would appear noteworthy that a similar diminution occurs in adrenalectomized dogs following withdrawal of extract (14). We believe these changes must be the result of the failure of the adrenals alone, since the presence of coincidental renal disease was excluded by the absence of antecedent history, and the failure to find casts, albumin, etc., in any of the numerous specimens of urine examined.

\section{SUMMARY}

Studies are reported of the effects of water restriction and of the forced water ingestion, respectively, in a patient suffering with chronic adrenal cortical insufficiency who, throughout the period of observation, had received a high daily intake of sodium chloride. For several months previous to our studies the patient's condition had been adequately controlled by a similar high daily intake of sodium chloride and by the ingestion of fluids as desired.

During the period in which water was restricted our studies indicated a diminished ability of the patient to concentrate sodium and chloride in the urine, and a significant retention of these ions by the individual. During this same period there was a marked elevation in the concentrations of sodium and chloride in the blood serum but, since the increase in concentration of these components was associated with a shrinkage of the serum 
volume, the total quantities of sodium and chloride in the circulating serum were actually reduced.

A normal individual studied under similar conditions excreted sodium and chloride in concentrations approximately 60 per cent greater than the patient and no retention of these ions occurred. In the normal individual, measurements of serum volume were essentially the same during the periods of fluid restriction and forced fluid ingestion.

Under the conditions of these observations the simple restriction of water resulted in the development of symptoms of severe adrenal insufficiency. Resumption of a normal intake of water resulted in a return of the patient to her normal state of health.

The forced ingestion of water in this patient had no appreciable influence upon the serum volume or the concentrations of sodium and chloride in the serum.

\section{PROTOCOL}

N. P. (Hospital Number 35-19589), a 54-year-old Italian-born white woman, the sole support of her family, had worked at a loom in a woolen mill for the previous twenty years. At the age of thirty-two she suffered from pleurisy and an abdominal enlargement relieved by paracentesis. Progressive weakness, anorexia, and pigmentation were first noted in the fall of 1934 and she was advised to take sodium chloride. The symptoms increased, however, and a year later, because of extreme weakness, occasional vomiting, marked pigmentation, and a loss of 46 per cent of body weight, the patient was admitted to the University Hospital.

Upon examination, she appeared thin, tired, and weak, with dry, inelastic skin hanging loosely in folds. A diffuse, muddy brown pigmentation was present, with accentuation upon the lips, neck, distal portions of the extremities, and several scars. It was also present at the lingual borders, and upon the buccal mucosa at points of contact with the teeth. Blood pressure was 108 $\mathrm{mm} . \mathrm{Hg}$ systolic and 78 diastolic. The right half of the thoracic cage was flattened, and expanded poorly with respiration. Resonance in this area was impaired, and the transmission of voice and breath sound was poor. There was also a right ovarian cyst.

Laboratory data on admission were: Erythrocytes, 4,400,000; hemoglobin 13.3 grams per $100 \mathrm{ml}$; ; leukocytes 8,100 with a normal differential distribution. The cell volume was 49 per cent, with a cell volume index of 1.23 . Urine analysis revealed no abnormalities. The concentration of the urea nitrogen of the blood was $18 \mathrm{mgm}$. per
$100 \mathrm{ml}$. In the serum, the concentration of chlorides was 98.3 m.eq. per liter; total base, 135.9 m.eq. per liter; and cholesterol, $177 \mathrm{mgm}$. per $100 \mathrm{ml}$.

The patient was placed on a high intake of sodium chloride, and for six weeks showed a gradual improvement. During this period, the systolic blood pressure ranged between 110 and $92 \mathrm{~mm} . \mathrm{Hg}$ and the diastolic ranged between 72 and 64 . Abdominal pain in upper left quadrant was occasionally present, and three bloody, muous streaked stools were noted shortly before her discharge from the hospital.

Blood counts during the period of hospitalization remained practically unchanged, and urine analyses were essentially normal, although the range of specific gravities was low (1.005 to 1.012). Serological reactions were negative, and a normal glucose tolerance curve was obtained. Roentgenograms disclosed a thickening of the entire pleura on the right side, with calcification at the base, and multiple areas of calcification in the upper abdomen, which were not limited to adrenal areas.

The patient was readmitted in July 1935 because of an exacerbation of symptoms. Weakness had increased, vomiting frequently occurred, and abdominal pain in upper left quadrant was again distressing. In addition, there had developed multiple joint symptoms consisting of stiffness and a dull aching pain, aggravated by motion. The erythrocytes were now 5,400,000, and the hemoglobin was 15.9 grams per $100 \mathrm{ml}$. The urea nitrogen of the blood was $16 \mathrm{mgm}$. per $100 \mathrm{ml}$., and, in the serum, the chlorides were 99.8 m.eq. per liter; $\mathrm{CO}_{2}, 44$ volumes per cent; and cholesterol, $273 \mathrm{mgm}$. per $100 \mathrm{ml}$. Although the systolic blood pressure was $112 \mathrm{~mm} . \mathrm{Hg}$ the evidences of hemoconcentration, the episodes of vomiting, and the general appearance of the patient gave the impression that she was in a state of mild crisis.

Therapy, consisting of 18 grams of $\mathrm{NaCl}$ and $2.5 \mathrm{cc}$. of anterior pituitary extract daily, was begun, and in five days there was considerable improvement. Vomiting subsided, anorexia diminished, and the patient became ambulatory. Concurrently, the erythrocytes fell to $4,400,000$; the hemoglobin to 13.7 grams per $100 \mathrm{ml}$; the urea nitrogen to $9 \mathrm{mgm}$. per $100 \mathrm{ml}$. In the serum, the chlorides rose to 105.2 m.eq. per liter, and the sodium was found to be 125.0 m.eq. per liter. Continuation of this therapy for an additional three weeks resulted in no further improvement, the concentration of sodium in the serum remaining well below normal (123.9 m.eq. per liter); nor did weekly injections of $5 \mathrm{cc}$. of eschatin appear to have any added effect.

Therapy was then limited to the daily use of 6 grams of $\mathrm{NaHCO}_{3}$ and 9 grams of $\mathrm{NaCl}$. The concentration of sodium in the serum following this treatment was 127.8 m.eq. per liter. Although some anorexia, weakness, and discomfort in the various joints persisted, there was great clinical improvement and the patient was discharged six weeks later with instructions to continue this simple therapy.

She remained quite well until the development of an 
upper respiratory infection. Following this, anorexia and weakness increased, and the generalized arthritic pains became quite troublesome, causing chief concern in the mornings, and diminishing in severity as the day progressed. Although weakness and languor were a little more apparent, she did not seem to be in crisis. Results of analyses of blood and serum showed little variation from those of the previous discharge, with the exception of an elevation in urea nitrogen to $30 \mathrm{mgm}$. per $100 \mathrm{ml}$. of blood. Upon active resumption of $\mathrm{NaCl}$ and $\mathrm{NaHCO}_{3}$ therapy, an immediate improvement was noted.

Therapeutic results in this patient, while beneficial, had left much to be desired, and an effort was made to determine the effectiveness of one of the newer adrenal cortical extracts. The total intake of sodium chloride was lowered to 4 grams daily for seven days. On the fourth day the expected aggravation of symptoms was noted, and daily intramuscular injections of the extract were begun. In spite of this treatment a gradual progression into crisis occurred, which was relieved by a return to that form of therapy which previously had been most beneficial ( 9 grams $\mathrm{NaCl}$ and 6 grams $\mathrm{NaHCO}_{2}$ daily). Analysis of the serum confirmed the clinical impression that the cortical hormone, as used in this patient, was ineffective in preventing the development of crisis under conditions of salt restriction.

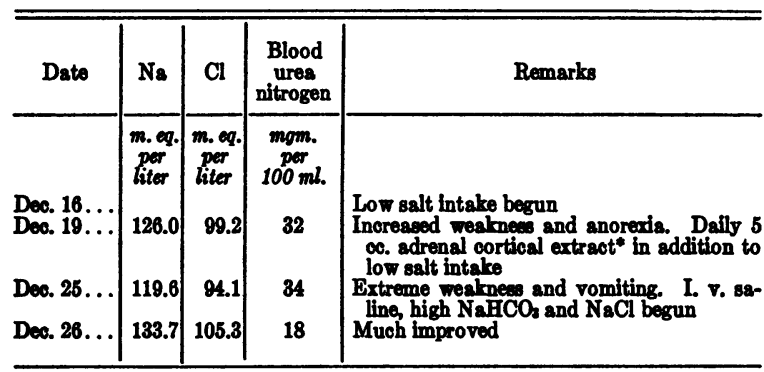

* Extract supplied by Upjohn and Co., Kalamazoo, Michigan.

Following this observation, the patient's clinical condition remained stationary under treatment consisting of daily administrations of 9 grams $\mathrm{NaCl}$ and 6 grams $\mathrm{NaHCO}_{2}$, although some weakness and varying degrees of anorexia persisted. An attempt to improve this status with the use of cortical extract in addition to the sodium therapy resulted in no apparent change in general appearance or subjective state. Studies of the serum were unsatisfactory in the evaluation of the effect of these injections since essentially normal electrolyte levels had been maintained by means of the sodium salts alone and further increases were not expected from specific treatment.

During the eight-week period which covered the studies reported in the text the patient received only sodium chloride. On this regimen the patient's general condition was not quite so satisfactory as when bicarbonate was also administered in conjunction with $\mathrm{NaCl}$. Periodically, there was vomiting and mild exacerbations of weakness. Whether this reflected merely the omission of bicarbonate or was due to the relatively high amount of potassium included in the special diet is problematical.

With the conclusion of the results reported, the patient desired to leave the hospital for a short time before attempting any further studies. Accordingly, she returned to her home in another city with instructions to take the sodium chloride and bicarbonate that had been most effective in relieving her symptoms. A sudden illness of two days' duration however, resulted in her death five weeks later. No autopsy was performed.

\section{BIBLIOGRAPHY}

1. Loeb, R. F., Atchley, D. W., Benedict, E. M., and Leland, J., Electrolyte balance studies in adrenalectomized dogs with particular reference to the excretion of sodium. J. Exper. Med., 1933, 57, 775.

2. Harrop, G. A., Soffer, L. J., Ellsworth, R., and Trescher, J. H., Studies on the sùprarenal cortex. III. Plasma electrolytes and electrolyte excretion during suprarenal insufficiency in the dog. $\mathrm{J}$. Exper. Med., 1933, 58, 17.

3. Swingle, W. W., Pfiffner, J. J., Vars, H. M., and Parkins, W. M., The effect of fluid deprivation and fluid intake upon the revival of dogs from adrenal insufficiency. Am. J. Physiol., 1934, 108, 144.

4. Harrop, G. A., Soffer, L. J., Nicholson, W. M., and Strauss, M., Studies on the suprarenal cortex. IV. The effect of sodium salts in sustaining the suprarenalectomized dog. J. Exper. Med., 1935, 61, 839.

5. Harrop, G. A., Nicholson, W. M., and Strauss, Margaret, Studies on the suprarenal cortex. V. The influence of the cortical hormone upon the excretion of water and electrolytes in the suprarenalectomized dơg. J. Exper. Med., 1936, 64, 233.

6. Swingle, W. W., Vars, H. M., and Parkins, W. M., A study of the blood volume of adrenalectomized dogs. Am. J. Physiol., 1934, 109, 488.

7. Harrop, G. A., The influence of the adrenal cortex upon the distribution of body water. Bull. Johns Hopkins Hosp., 1936, 59, 11.

8. Swingle, W. W., Pfiffner, J. J., Vars, H. M., and Parkins, W. M., The relation between blood pressure, blood urea nitrogen, and fluid balance of the adrenalectomized dog. Am. J. Physiol., 1934, 108, 428.

9. Swingle, W. W., Parkins, W. M., Taylor, A. R., and Hays, H. W., The influence of adrenal cortical hormone upon electrolyte and fluid distribution in adrenalectomized dogs maintained on a sodium and chloride free diet. Am. J. Physiol., 1937, 119, 684.

10. Magnus-Levy, C. von Noorden, Metabolism and Prac- 
tical Medicine. W. D. Keener, Chicago, 1907, p. 392.

11. Sherman, H. C., The Chemistry of Food and Nutrition. Macmillan Co., New York, 1935, 5th ed., Table 62, pp. 590-594.

12. Wilder, R. M., Kendall, E. C., Snell, A. M., Kepler, E. J., Rynearson, E. H., and Adams, Mildred, Intake of potassium, an important consideration in Addison's disease. Arch. Int. Med., 1937, 59, 367.

13. Sunderman, F. W., and Austin, J. H., The measure- ment of serum volume. Am. J. Physiol., 1936, 117, 474.

14. Stahl, J., Atchley, D. W., and Loeb, R. E., Observations on adrenal insufficiency. $\mathrm{J}$. Clin. Invest., 1936, 15, 41.

15. Sunderman, F. William, Studies of serum electrolytes. VII. The total base and protein components of the serum during lobar pneumonia with a note on the gastric secretion. J. Clin. Invest., 1931, 11, 615. 